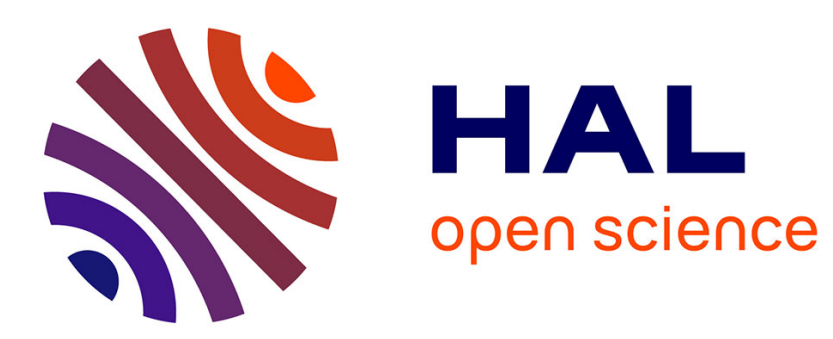

\title{
Isolation and partial purification of lipid-linked oligosaccharides from calf pancreas
}

Josette Badet, Roger W. Jeanloz

\section{To cite this version:}

Josette Badet, Roger W. Jeanloz. Isolation and partial purification of lipid-linked oligosaccharides from calf pancreas. Carbohydrate Research, 1988, 178 (1), pp.49-65. 10.1016/0008-6215(88)80101-0 . hal-01850331

\section{HAL Id: hal-01850331 \\ https://hal.science/hal-01850331}

Submitted on 27 Jul 2018

HAL is a multi-disciplinary open access archive for the deposit and dissemination of scientific research documents, whether they are published or not. The documents may come from teaching and research institutions in France or abroad, or from public or private research centers.
L'archive ouverte pluridisciplinaire HAL, est destinée au dépôt et à la diffusion de documents scientifiques de niveau recherche, publiés ou non, émanant des établissements d'enseignement et de recherche français ou étrangers, des laboratoires publics ou privés. 


\title{
ISOLATION AND PARTIAL PURIFICATION OF LIPID-LINKED OLIGO- SACCHARIDES FROM CALF PANCREAS*,+
}

\author{
JOSETTE BADET ${ }^{\ddagger}$ AND ROGER W. JEANLOZ ${ }^{\S}$ \\ Laboratory for Carbohydrate Research, Departments of Biological Chemistry and Medicine, Harvard \\ Medical School and Massachusetts General Hospital, Boston, Massachusetts 02114 (U.S.A.)
}

\begin{abstract}
Lipid-linked oligosaccharides containing at least five mannose residues $(0.7$ $\mathrm{nmol} / \mathrm{g}$ of tissue) were isolated from calf pancreas by chloroform-methanol-water extraction and purification on DEAE-cellulose and Sephadex LH-20, and affinity chromatography on concanavalin A-Sepharose in the presence of nonionic detergent. The addition, prior to the chromatographic steps, of ${ }^{14} \mathrm{C}$-labeled lipidlinked oligosaccharides (synthesized in vitro by calf pancreas microsomes in the presence of GDP-D- $\left[{ }^{14} \mathrm{C}\right]$ mannose and UDP-D- $\left[{ }^{14} \mathrm{C}\right]$ glucose, respectively) as internal standards, indicated a final yield ranging from 38 to $50 \%$. Analysis of the oligosaccharide residues by liquid chromatography of the lipid-free preparation, monitored by u.v. absorbance and radioactivity measurement of the tritiated compounds, indicated a heterogeneous mixture of oligosaccharides. Its components, ranging from $\operatorname{Man}_{5}(\mathrm{GlcNAc})_{2}$ to $\mathrm{Glc}_{3} \mathrm{Man}_{9}(\mathrm{GlcNAc})_{2}$, cochromatographed with the ${ }^{14} \mathrm{C}$-labeled derivatives from in vitro synthesis. Calf pancreas contains lipid intermediates bearing at least six mannose rcsidues, such as $\operatorname{Man}_{9}(\mathrm{GlcNAc})_{2}-P$ - $P$ lipid, in almost equal or even higher amounts than $\mathrm{Glc}_{3} \mathrm{Man}_{9}(\mathrm{GlcNAc})_{2}-P-P$ dolichol.
\end{abstract}

INTRODUCTION

In almost all the eucaryotes, the oligosaccharide $\mathrm{Glc}_{3} \mathrm{Man}_{9}(\mathrm{GlcNAc})_{2}$ is transferred en bloc from its dolichyl diphosphate derivative to an asparagine residue in nascent proteins (for reviews, see refs. 2 and 3); it is further processed into high-

\footnotetext{
${ }^{*}$ Dedicated to Professor Walter T. J. Morgan.

${ }^{+}$This is publication No. 1038 of the Robert W. Lovett Memorial Group for the Study of Diseases Causing Deformities, Harvard Medical School, and Massachusetts General Hospital, Boston, Massachusetts. This investigation was supported by research grant AM-03564 from the National Institute of Arthritis, Diabetes, Digestive \& Kidney Diseases. A preliminary communication has been presented (see ref. 1).

${ }_{\ddagger}^{\ddagger}$ Chargé de Recherches I.N.S.E.R.M. Present address: Laboratoire de Biotechnologie, Université Paris XII, Av. du Général de Gaulle, F-94010 Créteil, France.

${ }^{\S}$ To whom correspondence should be addressed.
} 
mannose, complex, or hybrid-type carbohydrate chains. Cell-culture studies using metabolic labeling suggested that this major lipid intermediate results from an ordered biosynthetic pathway ${ }^{4}$. In vitro studies ${ }^{5.6}$, as well as cell culture in glucosedepleted medium ${ }^{7}$, led to the description of alternative biosynthetic pathways, but these observations were made for limiting substrate concentrations ${ }^{7.8}$.

Study of individual steps of biosynthesis, as well as structural analysis of the carbohydrate and the lipid components of each intermediate, would be most informative if milligram amounts of lipid-linked oligosaccharides were available. Such studies as the transfer through the endo-reticular membrane by use of synthetic probes could also be undertaken. This has not been feasible until now, because of the minute amounts of these compounds present in tissues. They have been estimated at $1 \mathrm{nmol} / \mathrm{g}$ of tissue ${ }^{y, 10}$ or per $10^{9}$ cells $^{11}$. Oligosaccharide lipids have been previously isolated from pig liver ${ }^{12.13}$, calf thyroid ${ }^{9}$, and calf pancreas ${ }^{14}$; they contained D-glucose, D-mannose, and 2-acetamido-2-deoxy-D-glucose in ratios of $0: 1: 1$ (ref. 13), 1-2:11:2 (ref. 9), and $0.5: 2.5: 1$ to $1.5: 5: 1$ (ref. 14). We report herein the isolation and partial purification in milligram amounts of the higher molecular weight, lipid-linked oligosaccharides from calf pancreas by affinity chromatography on concanavalin A-Sepharose. Evidence is presented for the existence of a heterogeneous mixture in which the $\operatorname{Man}_{9}(\mathrm{GlcNAc})_{2}-P$-P-lipid derivative is the main compound.

\section{RESULTS AND DISCUSSION}

Calf pancreas microsomes incorporated radioactivity from, respectively, GDP-D- $\left[{ }^{14} \mathrm{C}\right]$ mannose and UDP-D- $\left[{ }^{14} \mathrm{C}\right]$ glucose into lipid-bound oligosaccharides extracted with 4:4:1 (v/v) chloroform-methanol-water (Fig. 1), as previously reported ${ }^{14.15}$. Upon incubation with GDP-D- $\left[{ }^{14} \mathrm{C}\right]$ mannose, eight major labeled products were obtained, ranging in size from $\operatorname{Man}_{5}(\mathrm{GlcNAc})_{2}{ }^{-}$to $\mathrm{Glc}_{3} \mathrm{Man}_{9}(\mathrm{GlcNAc})_{2}-P$ - $P$-Dol (Figs. 1 and $2 \mathrm{~A}$ ). Whatever the microsomal preparation, the main lipid-derived oligosaccharide was $\operatorname{Man}_{6}(\mathrm{GlcNAc})_{2}$, accounting for 25 to $35 \%$ of the radioactivity.

Man- $P$-Dol has been shown to be directly involved as a donor of D-mannopyranosyl residues in the elongation of the heptasaccharide-lipid ${ }^{16}$. Thus, when incubations of microsomal preparations from lactating bovine mammary tissue were supplemented with dolichyl phosphate, a shift in the relative proportion of the isomers synthesized was observed ${ }^{5.6}$, giving rise to the major ordered sequence as proposed by Chapman et al. ${ }^{4}$. The distribution observed in calf pancreas microsomal incubations might be directly related to a limiting concentration of Man-P-Dol in the in vitro studies.

Chloroform-methanol-water extracts from calf pancreas microsomal preparations incubated with UDP-D-[ $\left.{ }^{14} \mathrm{C}\right]$ glucose contained three lipid-derived oligosaccharides (Figs. 1 and $2 \mathrm{~B}$ ), the main one being $\mathrm{Glc}_{3} \mathrm{Man}_{9}(\mathrm{GlcNAc})_{2}$ (refs. $17,18)(70-75 \%)$. 


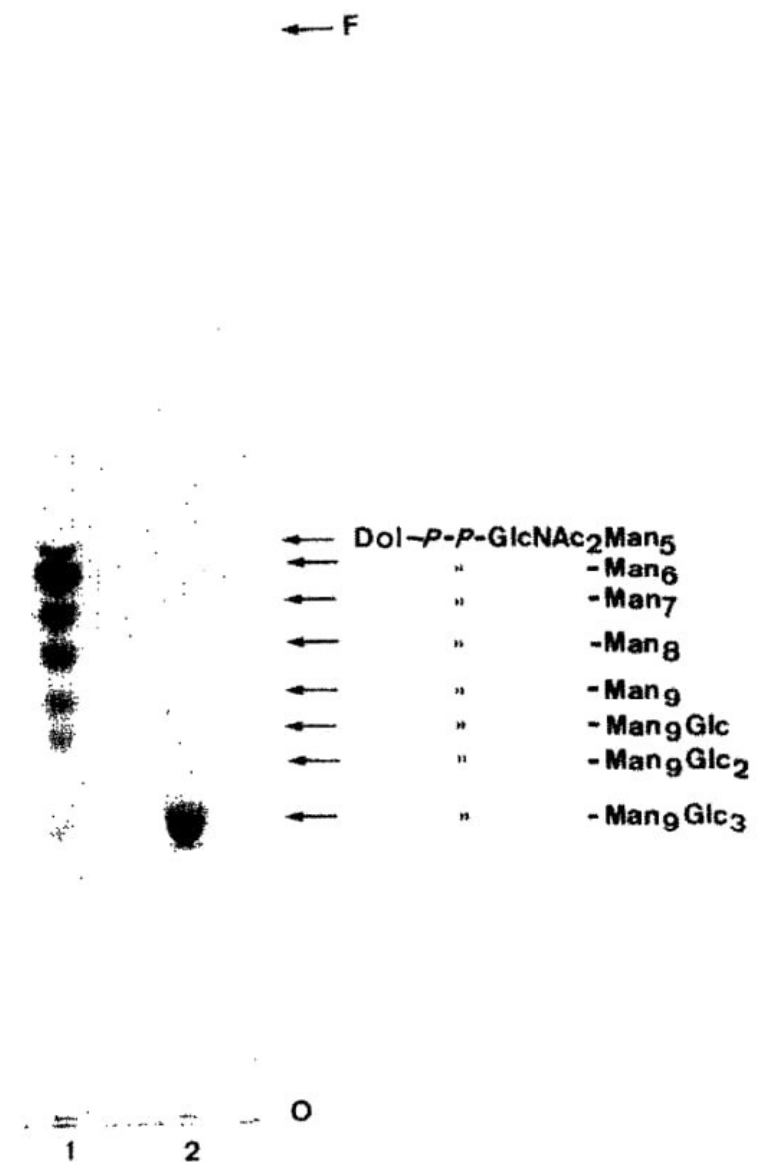

Fig. 1. Thin-layer chromatography in solvent $D$ of ${ }^{14} \mathrm{C}$-labeled, lipid-linked oligosaccharides extracted with solvent $B$ from microsomes incubated with GDP-D- $\left[{ }^{14} \mathrm{C}\right]$ mannose $(12000$ d.p.m., lane 1) or UDPD- $\left[{ }^{14} \mathrm{C}\right]$ glucose (7 500 d.p.m., lane 2), as described under "Standard lipid-linked oligosaccharides" in the Experimental section. The radioactivity was detected by exposing the plate to RT-5 film for $41 \mathrm{~h}$. For identification, the mol. wts. of the released oligosaccharides were determined on a calibrated Bio-Gel P-4 column and the composition analyzed by l.c. (Figs. 2A and B).

The isolation of lipid intermediates is difficult owing to the low natural concentration $^{9.10}$ and the absence of specific properties that could differentiate them from other lipids. In addition, the apparent composition of the lipid-linked oligosaccharides could reflect some degradation occurring during the extraction procedure ${ }^{19}$. To test for this, a series of experiments was performed in which ${ }^{14} \mathrm{C}$ labeled, lipid-linked oligosaccharides were introduced as internal standards, prior to the extraction of microsomes and total pancreas tissue. Only $30 \%$ of the expected radioactivity was extracted with chloroform-methanol, but $75-90 \%$ of the theoretical amounts passed into chloroform-methanol-water. After partial purification according to Method 1 (see Experimental section), the proportions of the added internal standards, determined by l.c. separation of the free oligosaccharides obtained from the lipid intermediates, were preserved to a reasonable degree (Table I). The somewhat higher deviations observed for the $\mathrm{Man}_{5}, \mathrm{Man}_{9}$, 

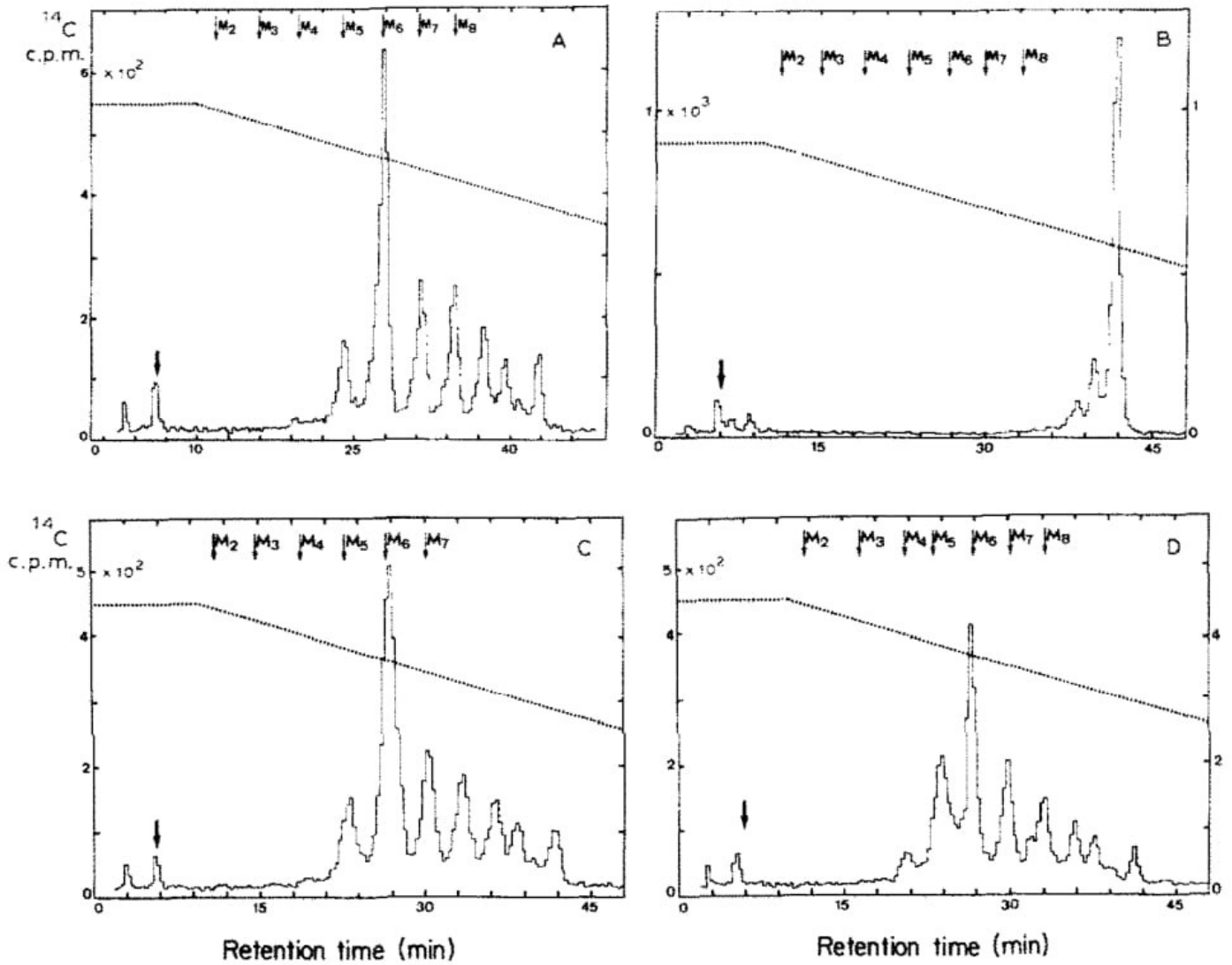

Fig. 2. L.c. profiles of reduced, $\left[{ }^{14} \mathrm{C}\right]$ mannose- and $\left[{ }^{14} \mathrm{C}\right]$ glucose-containing oligosaccharides, released by mild acid hydrolysis of lipid intermediates. Elution as described in the Experimental section. $\mathrm{M}_{2}$ to $\mathrm{M}_{8}$ indicate the positions of cochromatographed, authentic $\mathrm{Man}_{2-8}(\mathrm{GlcNAc})_{2}$ oligosaccharides (from calf urine) detected by absorbance at $190 \mathrm{~nm}$; the arrow indicates di- $N$-acetylchitobiose. (A) $\left[{ }^{14} \mathrm{C}\right]$ Mannose-labeled oligosaccharides derived from lipid intermediates extracted with solvent $B$ (13000 d.p.m.); (B) $\left[{ }^{14} \mathrm{C}\right]$ glucose-labeled oligosaccharides derived from lipid intermediates extracted with solvent $B$ (8500 d.p.m.); (C) $\left[{ }^{14} \mathrm{C}\right]$ mannose-labeled oligosaccharides obtained by elution of a Con A-Sepharose column (13000 d.p.m., Fig. 3D); and (D) $\left[{ }^{14} \mathrm{C}\right]$ mannose-labeled oligosaccharides obtained by hydrolysis of intermediates eluted from a Con A-Sepharose column (11 500 d.p.m.. Fig. 3A).

and $\mathrm{Gic}_{3} \mathrm{Man}_{9}$ compounds probably reflected the slight differences observed in one out of four experiments. With this exception, the variations between pancreas tissue and microsomal extracts were not significant. These results indicate the absence of a specific loss of lipid intermediates containing four or more mannose residues during extraction.

Lipid intermediates containing the pentasaccharide core $\operatorname{Man}_{3}(\mathrm{GlcNAc})_{2}$ have been shown ${ }^{20,21}$ to bind to concanavalin $\mathrm{A}$. Indeed, the radioactively labeled lipid-linked oligosaccharides were retained on the Con A-Sepharose column and then eluted as a broad peak with a buffer containing $0.1 \mathrm{M}$ methyl $\alpha$-D-glucopyranoside or methyl $\alpha$-D-mannopyranoside (Figs. 3A and 3B). Binding of the lipid intermediates to this column seems to involve a specific interaction, as the inter- 
TABLE I

\begin{tabular}{|c|c|c|}
\hline \multirow{2}{*}{$\begin{array}{l}\text { Lipid-derived } \\
\text { oligosaccharides }\end{array}$} & \multicolumn{2}{|c|}{ Relative distribution (\%) } \\
\hline & $\begin{array}{l}\text { Initial } \\
\text { values }^{b}\end{array}$ & Purified oligosaccharides ${ }^{c}$ \\
\hline $\mathrm{Man}_{4} \mathrm{GlcNAc}_{2}$ & 1.7 & $2.2 \pm 0.7^{d}$ \\
\hline $\mathrm{Man}_{5} \mathrm{GlcNAc}_{2}$ & 9.1 & $10.4 \pm 2.6$ \\
\hline $\operatorname{Man}_{6} \mathrm{GlcNAc}_{2}$ & 23.7 & $25.8 \pm 2.8$ \\
\hline $\mathrm{Man}_{7} \mathrm{GlcNAc}_{2}$ & 10.5 & $11.9 \pm 0.6$ \\
\hline $\mathrm{Man}_{8} \mathrm{GlcNAc}_{2}$ & 9.3 & $10.1 \pm 0.4$ \\
\hline $\mathrm{Man}_{9} \mathrm{GlcNAc}_{2}$ & 7.5 & $8.2 \pm 1.5$ \\
\hline Glc. $\mathrm{Man}_{9} \mathrm{GlcNAc}_{2}$ & 7.6 & $6.6 \pm 0.4$ \\
\hline $\mathrm{Glc}_{2} \mathrm{Man}_{9} \mathrm{GlcNAc}_{2}$ & 5.1 & $5.5 \pm 1.6$ \\
\hline $\mathrm{Glc}_{3} \mathrm{Man}_{9} \mathrm{GlcNAc}_{2}$ & 25.3 & $19.4 \pm 4.6$ \\
\hline
\end{tabular}

${ }^{a}$ The pool of extracts by solvents $A$ and $B$ from microsomes incubated with GDP-D- $\left[{ }^{14} \mathrm{C}\right]$ mannose and UDP-D- $\left[{ }^{14} \mathrm{C}\right]$ glucose, respectively, was added to pancreas and microsomal lyophilizates. The purification of endogenous lipid intermediates was carried out as described under Method 1 (small scale) in the Experimental section. The oligosaccharides were released by mild acid hydrolysis, reduced, and analyzed by 1.c. ${ }^{b}$ Radioactively labeled intermediates used for addition to lyophilizates. ${ }^{C}$ Recovered from tissue or microsomal extracts. Relative distribution calculated from radioactivity determinations: the samples analyzed by l.c. contained 12500 to 21000 d.p.m. ${ }^{d}$ Mean and standard deviation of four experiments.

mediates did not bind to either unsubstituted Sepharose-4B (Fig. 3C) or lentil lectin-Sepharose (not shown).

The pattern of elution from the Con A-Sepharose columns of the oligosaccharides released from the lipid intermediates (Fig. 3D), was asymmetrical and similar to that of the original lipid intermediates (Fig. 3A), suggesting that the lipid component is not involved in the tail effect; this, therefore, might result from a stronger interaction with the $\alpha$ - $(1 \rightarrow 6)$-linked, terminal D-mannopyranosyl groups ${ }^{22}$. The oligosaccharides eluted from the Con A-Sepharose column (Fig. 3D) showed the same distribution, on analysis by l.c. (Fig. 2C), as the control, radioactively labeled oligosaccharides that were derived from $\mathrm{D}-\left[{ }^{14} \mathrm{C}\right]$ mannose-labeled intermediates obtained by chloroform-methanol-water extraction and not fractionated on the Con A-Sepharose column (Fig. 2A). However, l.c. analysis (Fig. 2D) of the oligosaccharides released from the Con A-Sepharose eluate (Fig. 3A) showed a decrease in the amounts of $\mathrm{Man}_{6^{-}}, \mathrm{Man}_{9^{-}}$, and $\mathrm{Glc}_{3} \mathrm{Man}_{9^{-}}(\mathrm{GlcNAc})_{2}$ compounds, and an increase of the $\operatorname{Man}_{5}(\mathrm{GICNAc})_{2}$ compound. This difference was not observed when larger amounts of lipid intermediates were purified by Con ASepharose affinity chromatography (Fig. 4).

The higher mol. wt., natural lipid-linked oligosaccharides were isolated on a large scale from calf pancreas tissue by use of differential solvent partition, ionexchange chromatography on DEAE-cellulose (Fig. 5A), gel filtration on Sephadex LH-20 (Fig. 5B), and affinity chromatography on concanavalin A- 


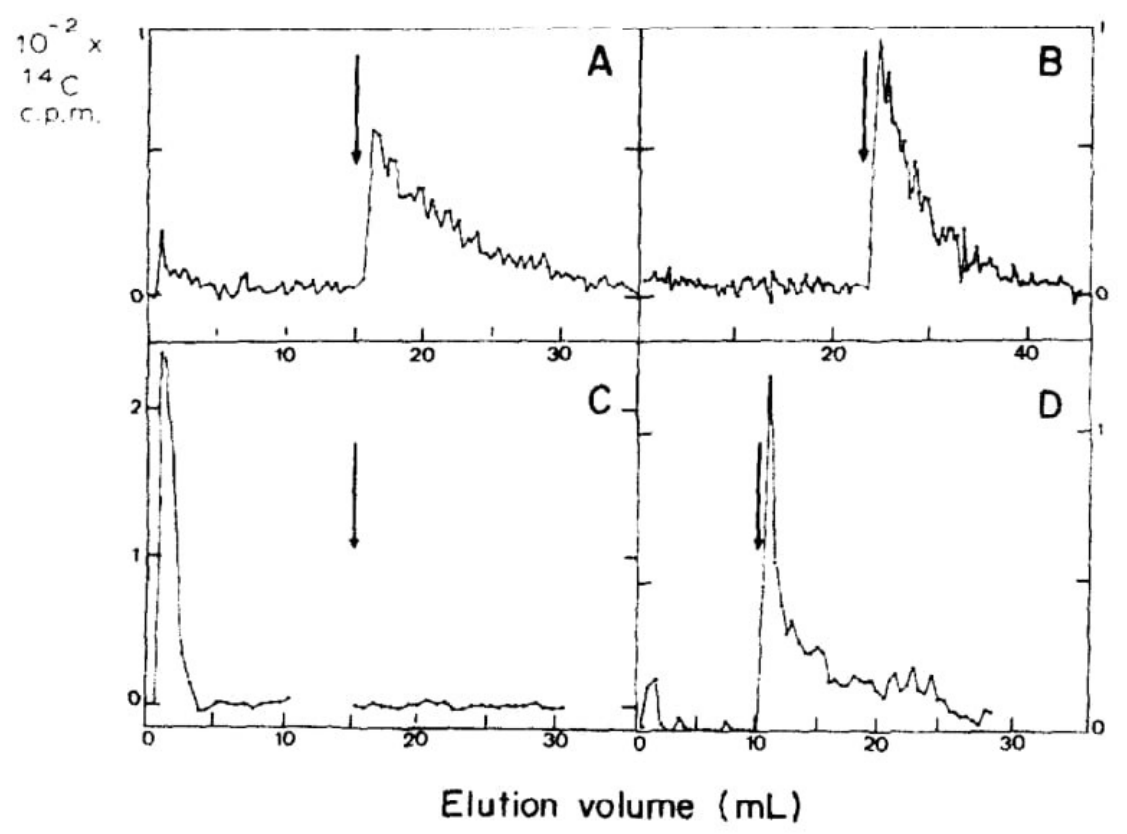

Fig. 3. Elution profiles from columns of Con $A-S e p h a r o s e ~(A, B$, and D) and Sepharose-4B (C) in $1 \%$

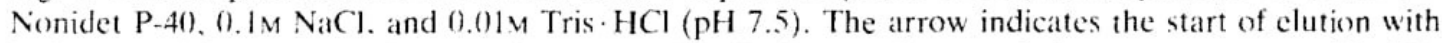
buffer containing $0.1 \mathrm{M}$ methyl $\alpha$-1)-glucopyranoside (A. B, and C) or methyl $\alpha$-D)-mannopyranoside (D). (A) $\left.{ }^{1 .} \mathrm{C}\right]$ Mannose-labeled lipid intermediates extracted with solvent $B(0.6 \times 2.1 \mathrm{~cm}$ column); (B) $\left.\left.\right|^{i 4} \mathrm{C}\right]$ glucose-labeled lipid intermediates extracted with solvent $B(0.6 \times 2.1 \mathrm{~cm}$ column); (C) $\left[{ }^{1+4} \mathrm{C}\right]$ mannose-labeled lipid intermediates $\left(0.6 \times 2.1 \mathrm{~cm}\right.$ column); and (D) $\left[{ }^{1+} \mathrm{C} \mid\right.$ mannose-labeled oligosaccharides obtained by acid hydrolysis of lipid intermediates $(10.7 \times 1.3 \mathrm{~cm}$ column): elution without Nonidet P-40.

Sepharose (Fig. 5C). After desalting in a Bio-Gel P-6DG column (Fig. 5D), the lipid intermediates were obtained free of detergent by DEAE-cellulose chromatography (Fig. 5E). The final recovery, based on the initially added labeled standards. ranged from 38 to $50 \%$.

The changes in the molar ratio of 2-acetamido-2-deoxyglucose to phosphorus during the purification steps (Table II) showed that the major part of the phospholipid contaminants had been eliminated, and that the affinity chromatography on Con A-Sepharose was an efficient step of purification. Nevertheless the final value of $1: 7$ for the 2-acetamido-2-deoxyglucose to phosphorus ratio (instead of the theoretical value of $1: 1$ ) indicated appreciable amounts of phosphate-containing contaminants. Based on the 2-acetamido-2-deoxyglucose determination. more than $0.7 \mathrm{nmol}$ of lipid-linked oligosaccharides was obtained per $\mathrm{g}$ of pancreas tissue.

The l.c. analysis of oligosaccharides released by endo- $N$-acetyl- $\beta$-D-glucosaminidase $\mathrm{H}$ (endo-H) from large scale-purified lipid intermediates was monitored by u.v. absorbance. It showed (Fig. 4A) seven peaks that cochromatographed with internal, ${ }^{14} \mathrm{C}$-labeled standards ranging in size from $\operatorname{Man}_{6} G \mathrm{GNAc}$ to $\mathrm{Glc}_{3} \mathrm{Man}_{4} \mathrm{GlcNAc}$. L.c. of a tritiated, mild-acid hydrolyzate of the lipid inter- 


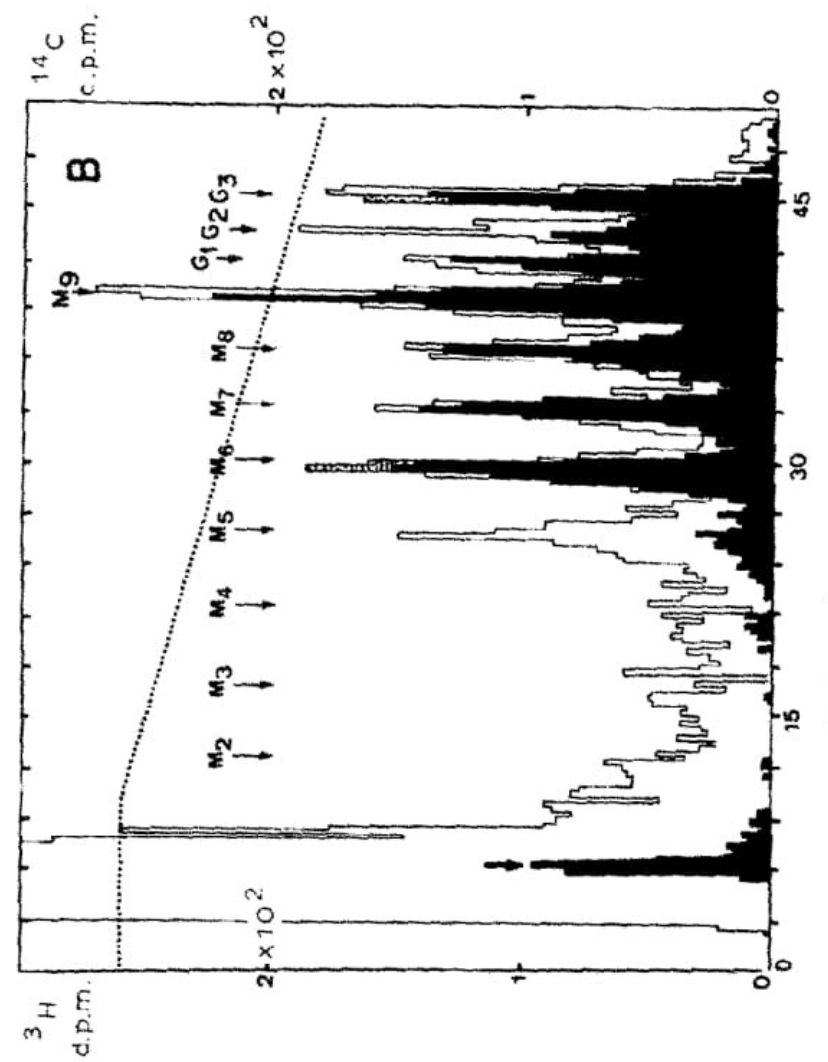

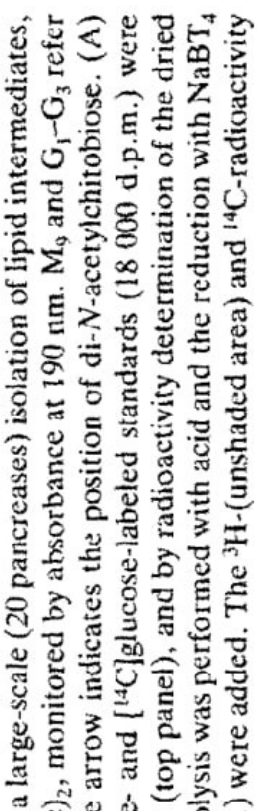

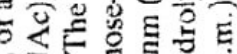

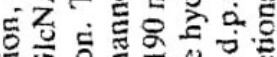

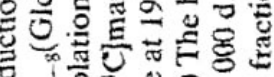

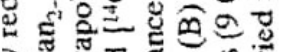

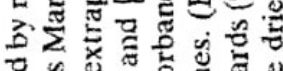

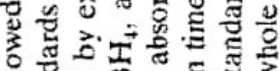

政问造

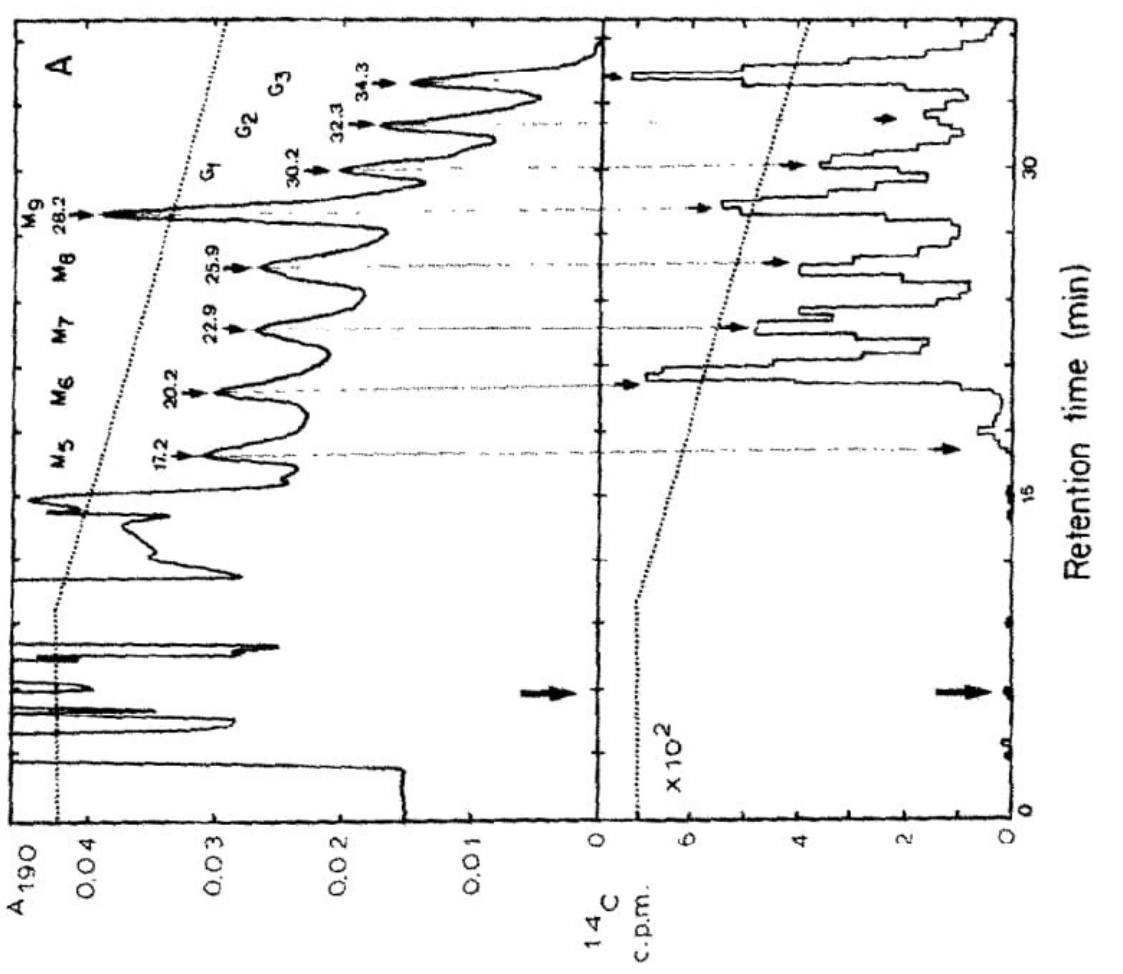

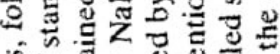

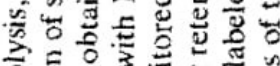

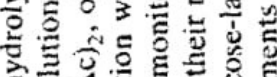

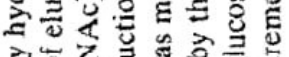

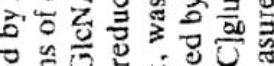

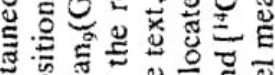

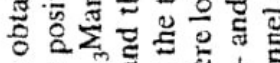

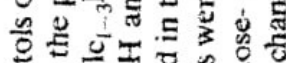

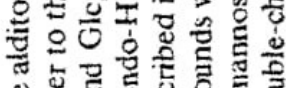

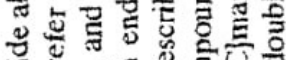

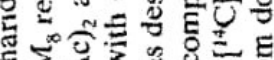

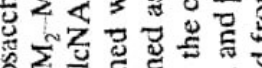

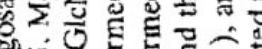
은?

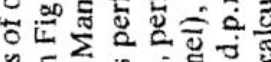

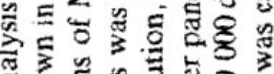

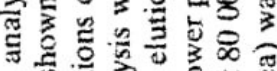

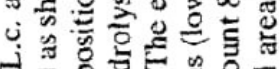

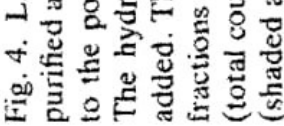




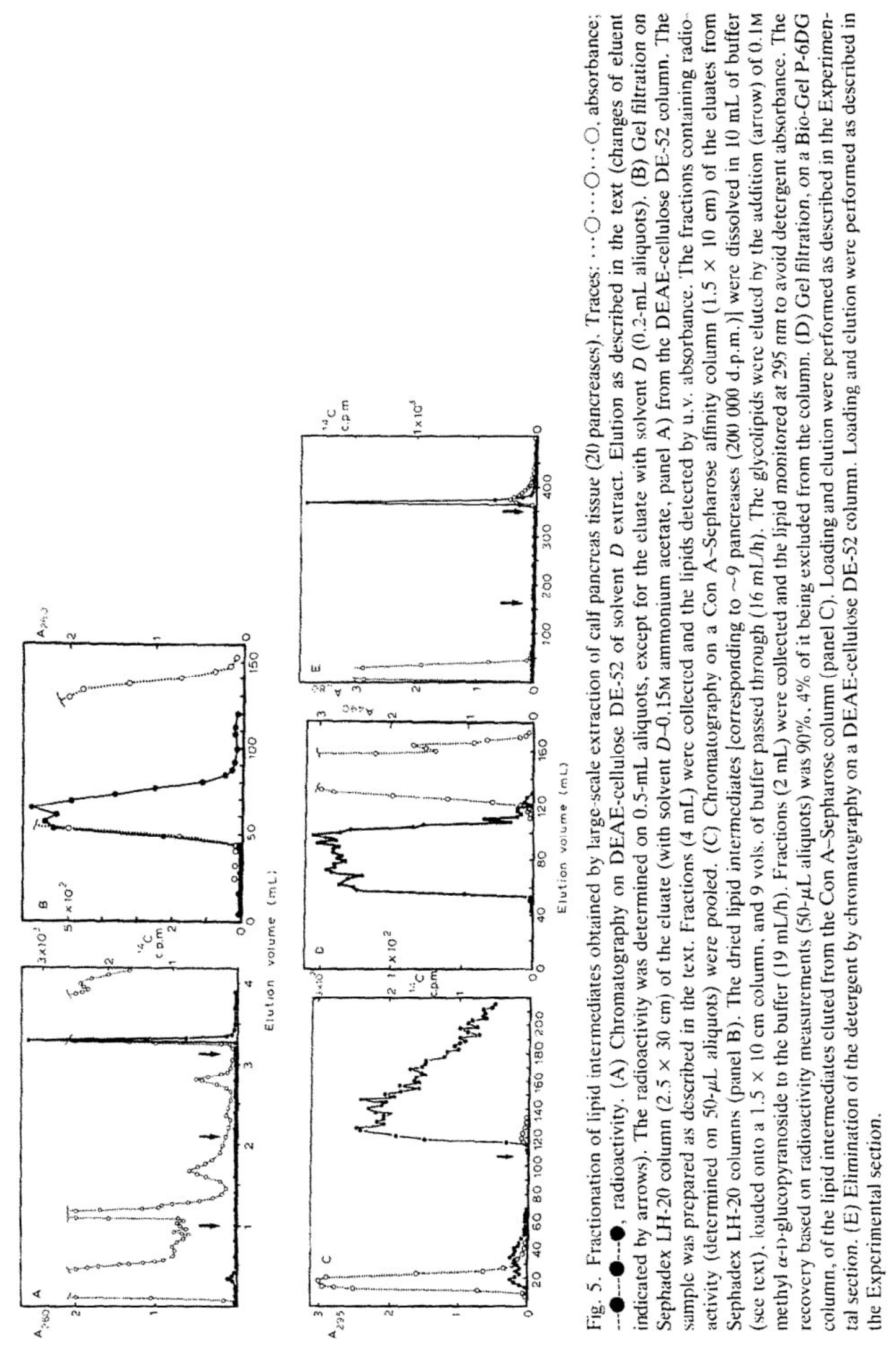


TABLE II

MOLAR RATIOS OF HEXOSE. PHOSPHORUS. AND 2-ACETAMIDO-2-DEOXYGLUCOSE DURING LARGE-SCALE PURIFICATION OF LIPID INTERMEDIATES ${ }^{a}$

\begin{tabular}{|c|c|c|c|}
\hline \multirow[t]{2}{*}{ Steps of purification } & \multicolumn{3}{|c|}{ Molar proportions } \\
\hline & GlcNAc & Hexose & Phosphorus \\
\hline Extraction with solvent $D$ & 1.0 & $22 \pm 9$ & $60 \pm 12$ \\
\hline $\begin{array}{l}\text { DEAE-cellulose DE-52 and } \\
\text { Sephadex LH-20 chromatography }\end{array}$ & 1.0 & $6.3 \pm 0.6$ & $24 \pm 5$ \\
\hline $\begin{array}{l}\text { Con A-Sepharose, Bio-Gel P-6DG, and } \\
\text { DEAE-cellulose DE-52 chromatography }\end{array}$ & 1.0 & $5.5 \pm 0.9$ & $7.0 \pm 1.0$ \\
\hline Theoretical & 1.0 & $2.5-6.0$ & 1.0 \\
\hline $\begin{array}{l}\text { Oligosaccharides released } \\
\text { by acid hydrolysis }\end{array}$ & 1.0 & $6.2 \pm 0.7$ & \\
\hline
\end{tabular}

${ }^{a}$ The lipid intermediates were purified from $\sim 20$ pancreases $(400 \mathrm{~g})$ according to Method 2. The lyophilized product $(8.8 \mathrm{mg})$ contained $\sim 33 \mathrm{nmol}$ of lipid intermediates per $\mathrm{g}$ of tissue, based on GicNAc determination $\left(0.7 \mathrm{nmol} / \mathrm{g}\right.$ of tissue). ${ }^{b} \mathrm{GIcNAc}$ taken as 1.0 . 'The calculated ratio of GlcNAc to hexose was 4.2 , based on the 1.c. analysis of the sugar components (see Fig. 4).

mediates gave a similar profile (Fig. 4B); in addition, it showed that the compounds detected by u.v. absorbance (Fig. 4A) at short retention times might be contaminants from the endo- $H$ treatment. The cochromatography of the tritiated, lipid-free oligosaccharides with the reduced, externally added, ${ }^{14} \mathrm{C}$-labeled standards was evidence for the identity of the lipid intermediates present in calf pancreas tissue with the in vitro synthesized derivatives. In agreement with Kobata's ${ }^{23}$ proposal for the specificity of the endo-H enzyme, the $\operatorname{Man}_{2-5}(\mathrm{GlcNAc})_{2}$ compounds have been shown to be resistant to endo-H treatment ${ }^{24}$. But despite a slight quantitative difference in mobility $v s$. the standard, the oligosaccharides resulting from endo-H treatment included a component having the chromatographic properties of $\mathrm{a} \mathrm{Man}_{5}$ GlcNAc compound (Fig. 4), thus suggesting that the $\operatorname{Man}_{5}(\mathrm{GlcNAc})_{2}$ intermediate is cleaved by the enzyme. This discrepancy with previous results may be due to the presence of the lipid residue. Further studies of this $\mathrm{Man}_{5}$ GlcNAc compound were limited because of the small amount of material available.

The major lipid-linked oligosaccharide synthesized in cell culture from radioactive precursors has the composition ${ }^{19,25} \mathrm{Glc}_{3} \mathrm{Man}_{9}(\mathrm{GlcNAc})_{2}$. In contrast, the natural lipid intermediates isolated from calf pancreas tissue (Fig. 4) were a heterogeneous mixture. Degradation by microsomal glucosidase activity ${ }^{19,26}$ or chemical degradation during the isolation are largely ruled out by the following observations. First, the co-purified, ${ }^{14} \mathrm{C}$-labeled internal standards did not show any modification in their relative proportions. Second, a series of experiments in which the ${ }^{14} \mathrm{C}$-labeled lipid intermediates were introduced before extraction did not show major variations (Table I). Third, similar data were obtained for a small scale 
preparation made by a modified Method 1 (not shown), where the temperature was better controlled and the extraction done in a very short time. Although some slight degradation during the isolation procedure cannot be completely excluded, the observations presented herein indicate that, besides the $\mathrm{Glc}_{3} \mathrm{Man}_{9}(\mathrm{GlcNAc})_{2}-$ lipid diphosphate, calf pancreas tissue contains higher or almost equal amounts of other high mol. wt. lipid intermediates. Among the lipid derivatives extracted by chloroform-methanol-water and containing at least five mannose residues, the $\operatorname{Man}_{9}(\mathrm{GlcNAc})_{2}$-lipid diphosphate was estimated to represent $19-28 \%$ of the oligosaccharide-lipid diphosphates. This preponderance of the non-glucosylated intermediates $(\sim 70 \%$ of the total $)$ is in agreement with the observation of Spiro et al. ${ }^{27}$ that the labeled oligosaccharides from glycolipids produced by the incubation of pancreas slices in the presence of radioactive precursors differed from those of other tissues (oviduct, thymus, kidney, and liver) in that they contained far less D-glucose. In bovine pancreas, most of the secreted ribonuclease (85-95\%) is nonglycosylated ${ }^{28,29}$, and so is the ribonuclease that is synthesized in vitro by pancreas slices ${ }^{30}$. However, when the incubation medium was supplemented with dolichyl phosphate, the newly synthesized ribonuclease was secreted in a glycosylated form ${ }^{30}$. The presence, in calf pancreas tissue, of "incomplete" lipid intermediates containing more than five mannose residues also argues for a limiting amount of dolichyl phosphate in this tissue. The large-scale purification described herein shows that it is possible to isolate, after a convenient scaling up, lipid intermediates in amounts sufficient for classical structure analysis of the carbohydrate components and, after further purification, analysis of the dolichol composition.

\section{EXPERIMENTAL}

Materials. - Suppliers of key chemicals were: New England Nuclear for GDP-D-[U- $\left.{ }^{14} \mathrm{C}\right]$ mannose $(10 \mathrm{GBq} / \mathrm{mmol})$ and sodium borotritide $(10.4 \mathrm{GBq} /$ $\mathrm{mmol})$; ICN for UDP-D-[U- $\left.{ }^{14} \mathrm{C}\right]$ glucose $(9.5 \mathrm{GBq} / \mathrm{mmol})$; Miles Laboratories Inc. for endo- $N$-acetyl- $\beta$-D-glucosaminidase $\mathrm{H}$ (endo $\mathrm{H}$ ) and crystallized bovine serum albumin; Pharmacia Fine Chemicals for Con A-Sepharose, lentil lectin-Sepharose4B, and Sephadex LH-20; Bio-Rad Laboratories for Bio-Gel P-4, Bio-Gel P-6DG, AG 50W-X8 $\left(\mathrm{H}^{+}\right)$, and $\mathrm{AG} 1-\mathrm{X} 8\left(\mathrm{HCO}_{2}^{-}\right)$; Whatman Ltd. for DEAE-cellulose DE-52; Eastman Kodak Co. for XR-5 film; Sigma Chemical Co. for Malachite Green (oxalate salt); E. Merck for precoated thin-layer plates of Silica gel G $(0.25$ $\mathrm{mm}$ thick, without fluorescent indicator); BDH Chemicals for Nonidet P-40 (NP$40)$; and Pfanstiehl Laboratories for methyl $\alpha$-D-glucopyranoside and methyl $\alpha$-Dmannopyranoside. All other chemicals were reagent grade commercial products.

Quantitative determinations. - Protein content was determined by the method of Lowry et al. ${ }^{31}$ using bovine serum albumin as a standard, hexose content by the phenol- $\mathrm{H}_{2} \mathrm{SO}_{4}$ method ${ }^{32}$, using D-mannose as a standard, and 2-acetamido-2deoxyglucose content by a modified Morgan-Elson method ${ }^{33}$ with di- $N$-acetylchitobiose as a standard. Phosphorus was determined by the method of Duck- 
Chong ${ }^{34}$ using $\mathrm{KH}_{2} \mathrm{PO}_{4}$ as a standard. Radioactivity was counted with a Packard Liquid Scintillation Spectrometer, Model 3375, using Hydrofluor (3 mL, National Diagnostic) as the "cocktail".

Preparation of microsomes. - Calf pancreas microsomes were prepared as described in Method 2 of Herscovics et al. ${ }^{15}$.

Standard lipid-linked oligosaccharides, oligosaccharides, and oligosaccharide alditols. - Unlabeled oligosaccharide standards, $\operatorname{Man}_{5-8}(\mathrm{GlcNAc})_{2}$, were isolated from pathological calf urines ${ }^{35} \cdot{ }^{14} \mathrm{C}$-Labeled, lipid-linked oligosaccharide standards were obtained from calf pancreas microsomes incubated for 30 min at $30^{\circ}$ in $1 \mathrm{~mL}$ of $40 \mathrm{~mm}$ Tris-maleate buffer, $10 \mathrm{mM}$ in $\mathrm{MnCl}_{2}$ and containing $4.5 \mathrm{kBq}$ of GDP-D$\left[{ }^{14} \mathrm{C}\right]$ mannose, at $\mathrm{pH} 6.3$, or UDP-D- $\left[{ }^{14} \mathrm{C}\right]$ glucose, at $\mathrm{pH}$ 5.3. The protein content was 4 or $8-10 \mathrm{mg} / \mathrm{mL}$ according to the microsomal preparation. The ${ }^{14} \mathrm{C}$-labeled products Man- $P$-Dol, Glc- $P$-Dol, and $\operatorname{Man}_{0-5}(\mathrm{GlcNAc})_{2}-P$ - $P$-Dol were extracted with 2:1 (v/v) chloroform-methanol (solvent $A$ ), and $\operatorname{Man}_{4-9}(\mathrm{GlcNAc})_{2^{-}}$and $\mathrm{Glc}_{1-3} \mathrm{Man}_{9}(\mathrm{GlcNAc})_{2}-P$-P-Dol with $4: 4: 1$ (v/v) chloroform-methanol-water (solvent $B$ ). A series of several incubation mixtures gave better yields than a single large-scale preparation.

Oligosaccharides were released by mild acid hydrolysis. A sample, dried under $\mathrm{N}_{2}$, was dissolved in ice-cold $0.1 \mathrm{M} \mathrm{HCl}(1 \mathrm{~mL})$. The solution was then heated for $20 \mathrm{~min}$ at $90^{\circ}$, being shaken three times during this period, cooled to $4^{\circ}$, and treated with cold $\mathrm{M} \mathrm{NaOH}(0.1 \mathrm{~mL})$. The hydrolyzate was desalted on a column of AG 1-X8 anion-exchange resin $\left(\mathrm{HCO}_{2}^{-} ; 1 \mathrm{~mL}\right)$ overlaid with $\mathrm{AG} 50 \mathrm{~W}-\mathrm{X} 8$ cationexchange resin $\left(\mathrm{H}^{+} ; 1 \mathrm{~mL}\right)$. This column was eluted with water $(3 \times 1 \mathrm{~mL})$ and the effluent lyophilized. When the sample contained too much lipid, or in order to monitor the hydrolysis yield, extraction of the water-soluble oligosaccharides was performed prior to desalting by the addition of solvent $A(5 \mathrm{vol}$.) to the neutralized hydrolyzate. After mixing, the whole was kept for $20 \mathrm{~min}$ at room temperature, mixed again, and centrifuged. The water (upper) phase was kept, and replaced by the same volume of $3: 48: 47(\mathrm{v} / \mathrm{v})$ chloroform-methanol-water (solvent $C$ ) for a second extraction. The pooled upper phases were then desalted as just described.

To avoid some partial degradations of the sugar chains by the mild acid hydrolysis, an alternative procedure was performed. The oligosaccharides were released from the lipid by digestion with endo- $N$-acetyl- $\beta$-D-glucosaminidase $\mathrm{H}$ according to Chalifour and Spiro ${ }^{36}$. The incubations were performed at the $\mathrm{pH}$ optimum (5.8) of Streptomyces plicatus endo-H.

The reduction of the oligosaccharides was accomplished by incubation overnight at room temperature with an excess of sodium borohydride in $5 \mathrm{~mm} \mathrm{NaOH}$. $\mathrm{M}$ Acetic acid was then added to destroy the excess of $\mathrm{NaBH}_{4}$, and borate ions were converted into boric acid by passage through a column $(0.6 \mathrm{~mL})$ of AG $50 \mathrm{~W}-\mathrm{X} 8$ $\left(\mathrm{H}^{+}\right)$cation-exchange resin. The effluent and two water washes $(1 \mathrm{~mL}$ each) were then lyophilized and the residues were dried by several additions and evaporations of toluene. Boric acid was removed by the addition of methanol (a few drops) and volatilization under a stream of $\mathrm{N}_{2}$. 
The mol. wts. of the unreduced, ${ }^{14} \mathrm{C}$-labeled oligosaccharides were determined in $0.1 \mathrm{M}$ pyridine acetate buffer, $\mathrm{pH} 5.0$, on a calibrated Bio-Gel P-4 column $(1 \times 200 \mathrm{~cm},<400 \mathrm{mesh})$. Both reduced and unreduced ${ }^{1+} \mathrm{C}$-labeled oligosaccharides were examined by cochromatography (l.c. under elevated pressure) with the oligosaccharide standards derived from calf urine.

Thin-layer chromatography. - T.l.c. was performed on precoated silica gel plates in 10:10:3 (v/v) chloroform-methanol-water (solvent $D$ ). Radioactively labeled substances were located by autoradiography.

Analysis of oligosaccharides by l.c. - The solution of oligosaccharides was passed through a $0.2-\mu \mathrm{m}$ filter (Rainin) and analyzed by 1.c. under elevated pressure $(\sim 7 \mathrm{MPa})$ with a Varian model 5020 apparatus, equipped with an UltraTechsphere $\mathrm{NH}_{2}$ column (HPLC Technology, $5 \times 250 \mathrm{~mm}, 5 \mu \mathrm{m}$ ), equilibrated with $65 \%(\mathrm{v} / \mathrm{v})$ acetonitrile in water. Elution under isocratic conditions was maintaincd for $10 \mathrm{~min}$, followed by a lincar gradient down to $55 \%$ acctonitrile. The flow rate and the slope of the gradient were adjusted according to the column behavior; the values were usually $1.2 \mathrm{~mL} / \mathrm{min}$ and $0.5 \% / \mathrm{min}$, respectively. For the chromatography of the unreduced oligosaccharides, which have shortened retention times, the column had to be cleaned by increasing the proportion of water up to $100 \%$ or by washing with an $\mathrm{H}_{3} \mathrm{PO}_{4}$ solution $(\mathrm{pH} 2.2)$. The elution of the oligosaccharides was monitored at $190 \mathrm{~nm}$ with a Spectroflow monitor, Model SF 770 (Kratos-Schoeffel Instr.). The fractions were collected every $0.3 \mathrm{~min}$ and taken to dryness prior to scintillation counting. The recovery estimated from radioactivity measurements for a set of four runs was $80 \pm 10 \%$.

Reduction of oligosaccharides with $\mathrm{NaBT}_{4}$. - The oligosaccharides (30$140 \mu \mathrm{M}$ ) were treated with a $2.1-2.6 \mathrm{mM} \mathrm{NaBT}_{4}$ solution in $5 \mathrm{~mm} \mathrm{NaOH}$ (total volume, 15-25 $\mu \mathrm{L}$ ) overnight at room temperature. The excess of borohydride was eliminated by addition of glacial acetic acid $(10 \mu \mathrm{L})$ and passage through a column $(0.1 \mathrm{~mL})$ of $\mathrm{AG} 50 \mathrm{~W}-\mathrm{X} 8\left(\mathrm{H}^{+}\right)$cation-exchange resin, the effluent being taken to dryness under $\mathrm{N}_{2}$, and the residuc alternately irrigated and dried, first with toluene, and then with methanol to eliminate boric acid.

Chromatography of lipid intermediates on DEAE-cellulose. - DEAEcellulose DE-52 was converted into the acetate form as described by Rouser et al. ${ }^{37}$. The column was packed in glacial acetic acid and thoroughly washed with methanol (10-15 bed vols.), the $\mathrm{pH}$ was determined, the resin was washed in 1:1 $(\mathrm{v} / \mathrm{v})$ chloroform-methanol, and then equilibrated with solvent $A$. Man- $P$-Dol and Glc- $P$-Dol were eluted with solvent $A-10 \mathrm{~mm}$ ammonium acetate, and oligosaccharides- $P$ - $P$-Dol with solvent $D$ containing 0.10 or $0.15 \mathrm{M}$ ammonium acetate. These solutions were prepared from a $2 \mathrm{M}$ ammonium acetate stock solution in methanol containing 3\% of acetic acid. After use, the column was washed successively with methanol, glacial acetic acid, and methanol, in which the cellulose was kept. The total recovery of radioactivity from this column was estimated to be 76 $\pm 14 \%(n=17)$. 
Concanavalin A-Sepharose affinity chromatography of labeled oligosaccharides (analytical scale). - Oligosaccharides (30 000-50 000 d.p.m.) released by mild acid hydrolysis from the lipid intermediates obtained by extraction with solvent $B$ were loaded onto a $0.6-\mathrm{mL}$ column equilibrated with $0.1 \mathrm{M} \mathrm{NaCl}$ and $10 \mathrm{~mm}$ Tris $\cdot \mathrm{HCl}, \mathrm{pH} 7.5$, at room temperature under conditions similar to those described by Ogata et al. ${ }^{38}$. After washing with buffer (15 bed vols.), the oligosaccharides were eluted by the addition of either methyl $\alpha$-D-mannopyranoside or $\alpha$-D-glucopyranoside (concentration $0.1 \mathrm{M}$ ) to the eluent. The recovery of radioactivity was quantitative. After lyophilization, the sample was taken up in water and desalted by passage through a $3.5-\mathrm{mL}$ column of $\mathrm{AG} 1-\mathrm{X} 8\left(\mathrm{HCO}_{2}^{-}\right)$anion-exchange resin, overlaid with $\mathrm{AG} 50-\mathrm{X} 8\left(\mathrm{H}^{+} ; 3.5 \mathrm{~mL}\right)$ cation-exchange resin. The effluent and water washes from the column were lyophilized, and the oligosaccharides freed from the methyl glycoside by gel filtration on a Bio-Gel P-4 column.

Concanavalin A-Sepharose affinity chromatography of ${ }^{14} \mathrm{C}$-labeled lipid intermediates. - Oligosaccharide lipid diphosphates (4000 to 25000 d.p.m.) extracted with solvent $B$ were chromatographed under the conditions just described for oligosaccharides, but in the presence of $1 \%$ NP-40. The lipid-bound oligosaccharides were eluted by methyl $\alpha$-D-mannopyranoside as well as by methyl $\alpha$-D-glucopyranoside.

The recovery of radioactivity from concanavalin A-Sepharose columns was $88 \pm 12 \%(n=5)$, both for oligosaccharides and lipid intermediates. The eluates were desalted by passage through a column $(2.2 \times 10 \mathrm{~cm})$ of Bio-Gel P-6DG equilibrated in $1 \% \mathrm{NP}-40$. The sample was loaded onto the column up to a volume corresponding to $34 \%$ of the bed volume. Elution at a flow rate up to $8 \mathrm{~mL} / \mathrm{cm}^{2} / \mathrm{h}$ resulted in a clear separation of the lipid intermediates and methyl glycosides, monitored respectively by radioactivity and hexose determination, with yields $>90 \%$. The eluate from the Bio-Gel P-6DG column was lyophilized, the residue was dissolved in solvent $A$, and the solution loaded onto a DE-52 column (10 mL), equilibrated with the same solvent. The nonionic detergent, monitored by u.v. absorbance, emerged in the void volume and, after washing the column with buffer (10-15 vols.), the radioactive compounds were eluted with solvent $D-0.1 \mathrm{M}$ ammonium acetate. Recoveries ranged from 55 to $75 \%$.

Desalting was achieved by gel filtration through a Sephadex LH-20 column $(55 \mathrm{~mL})$ in solvent $D$, with recoveries from 70 to $80 \%$. In an alternative procedure, the organic solvent was removed by evaporation in vacuo, and ammonium acetate by repeated lyophilizations after additions of water. A combination of both desalting methods was also used.

Small scale preparation of oligosaccharide-lipids from calf pancreas (Method 1). - Several frozen pancreases (kept at $-80^{\circ}$ ) were thawed at $4^{\circ}$ and, in an icebath, rapidly minced, then homogenized in ice-cold water or in $0.15 \mathrm{M} \mathrm{NaCl}$ with a Polytron PT 10-35 homogenizer (Brinkmann Instruments, Inc.) (three treatments 
at $35 \%$ of the highest speed). Each slurry was at once lyophilized*. In parallel, several microsomal preparations (each equivalent to one pancreas) were lyophilized and similarly extracted and fractionated in order to monitor the yields of the larger-scale preparation. $\mathrm{D}-\left[{ }^{14} \mathrm{C}\right]$ Mannose-labeled and $\mathrm{D}-\left[{ }^{14} \mathrm{C}\right]$ glucoselabeled, lipid-linked oligosaccharides $(200000$ d.p.m.) were added, before extraction, to each residue, to which was then added $5: 3(\mathrm{v} / \mathrm{v})$ methanol-water $(8 \mathrm{~mL} / 3 \mathrm{~g}$ of dried material) and, after $1 \mathrm{~h}$, chloroform, the final proportions being 5 vols. of solvent $A$ per $\mathrm{g}$ of dried material and $\mathrm{mL}$ of water (approximately the proportions of solvent $B$ ). The slurry was gently stirred overnight at $4^{\circ}$, then left undisturbed for $1 \mathrm{~h}$, and the lower phase was removed and replaced by the same volume of theoretical lower phase (86:14:1 chloroform-methanol-water). The lower phases were pooled and kept. The upper slurry was filtered on layers of cheesecloth pressed on a Whatman No. 4 filter paper. The solid material was washed on the filter successively with butanol and ice-cold water, and then extracted four times with solvent $D$ at $4^{\circ}(50 \mathrm{~mL} /$ pancreas and $25 \mathrm{~mL} /$ microsomal preparation, except for the first extraction where the volumes were double). The pooled extracts in solvents $A$ and $D$ were saponified according to Quesada-Allue and Parodi ${ }^{39}$. The samples were then loaded in solvent $A$ onto a DEAE-cellulose DE-52 column. The oligosaccharide-lipids, eluted with solvent $D-0.10$ or $0.12 \mathrm{M}$ ammonium acetate, were desalted by passage through a Sephadex LH-20 column, previously equilibrated with solvent $D$. The organic solvents were removed by evaporation in vacuo prior to lyophilization. The oligosaccharides released by mild acid hydrolysis were analyzed by l.c. The total recovery of radioactivity ranged from 34 to $62 \%$.

Large scale isolation of lipid-linked oligosaccharides from calf pancreas (Method 2). - At $4^{\circ}$ in an ice-bath, fresh calf pancreases $(\sim 1.5 \mathrm{~kg})$-were quickly trimmed and cut into small pieces, and the tissue was roughly homogenized with a Waring Blender (Waring Products Co., Model CB-5), then further with a Polytron as described in Method 1, and lyophilized. The lyophilizate was dissolved in 5:3 $(\mathrm{v} / \mathrm{v})$ methanol-water, the proportion of water being $60 \%$ of the initial tissue wet weight, by mixing in the Waring Blender for $5 \mathrm{~s}$ at the lowest speed, several times, before adding chloroform. The extract was treated as described in Method 1, but solvent $D$ extraction was performed only twice, for a total volume of $3.5 \mathrm{~L}$, which had been shown to be sufficient to dissolve most of the lipid-linked oligosaccharides. Only the extracts with solvent $D$ were kept in order to avoid doing an alkaline hydrolysis step. D- $\left[{ }^{14} \mathrm{C}\right]$ Mannose- and D- $\left[{ }^{14} \mathrm{C}\right]$ glucose-labeled, lipid-linked oligosaccharides (about 23000 d.p.m./pancreas) were then added.

The extract (from $\sim 20$ pancreases) was loaded in solvent $A$ onto a DEAEcellulose DE-52 column $(2.8 \times 18 \mathrm{~cm})$ (Fig. $5 \mathrm{~A})$. The column was washed successively with solvent $A(10-15$ bed vols.), methanol, and solvent $A-10 \mathrm{~mm}$ ammonium acetate. The lipid-bound oligosaccharides were eluted in a sharp peak with solvent

*In order to avoid thawing during the lyophilization, the frozen slurry was kept refrigerated. 
$D-0.15 \mathrm{M}$ ammonium acetate. The fractions $(10 \mathrm{~mL})$ were monitored by u.v. absorbance and radioactivity. The recovery of radioactivity in these preparativescale experiments was $\sim 65 \%$.

Gel filtration of the pooled fractions, dissolved in solvent $D$, was carried out on a column $(2.5 \times 30$ or $2.8 \times 33 \mathrm{~cm})$ of Sephadex LH-20 (Fig. 5B), equilibrated with solvent $D$, and eluted at $25 \mathrm{~mL} / \mathrm{h}$. Column filtration and repeated lyophilization with water were often combined to eliminate inorganic salts.

The lyophilized samples were completely soluble in a buffer consisting of $1 \%$ NP-40, 0.1 M NaCl, 0.01M Tris. $\mathrm{HCl}$ (pH 7.5), $\mathrm{mm} \mathrm{MgCl}_{2}, \mathrm{mM} \mathrm{CaCl}_{2}$, and $\mathrm{mm}$ $\mathrm{MnCl}_{2}$. The solution was loaded onto a Con A-Sepharose column $(1.5 \times 6.5-10$ $\mathrm{cm}$ ) equilibrated with the same buffer. After being loaded, the column was kept for several hours, then eluted with the aforementioned buffer at a maximum flow rate of $10 \mathrm{~mL} / \mathrm{cm}^{2} / \mathrm{h}$ (Fig. $5 \mathrm{C}$ ). To the eluting buffer was added $0.1 \mathrm{M}$ methyl $\alpha$-D-glucopyranoside and, when one bed vol. had passed through, the flow was stopped for at least $2 \mathrm{~h}$ to limit the tailing effect in the elution pattern. The total recovery of radioactivity was $>88 \%$.

After being used, the Con A-Sepharose column was washed successively with buffer prepared without the divalent metal cations ( 5 vols.), then with $0.5 \mathrm{M} \mathrm{NaCl}-$ $0.1 \mathrm{M}$ Tris $\cdot \mathrm{HCl}(\mathrm{pH} 8.5,10$ vols.), and $0.5 \mathrm{M} \mathrm{NaCl}-0.1 \mathrm{M}$ sodium acetate buffer ( $\mathrm{pH}$ $4.5,10$ vols.). The detergent and lipids obviously altered the capacity of the Con A-Sepharose columns, which were not used more than twice. Overloading sometimes occurred, causing some lipid intermediates to pass directly through the column. However, the unadsorbed material was retained when recycled on a fresh column.

The samples were obtained free of methyl glycosides and detergent by chromatography on Bio-Gel P-6DG and DE-52 as follows: The eluate from the Con A-Sepharose column (180 000 d.p.m.) was lyophilized, the residue was dissolved in deionized water $(50 \mathrm{~mL})$, and the solution loaded onto a column of Bio-Gel P-6 DG $(2.5 \times 29.5 \mathrm{~cm})$, previously equilibrated with $1 \%$ NP-40. Fractions $(2.1 \mathrm{~mL})$ were collected at a flow rate of $26 \mathrm{~mL} / \mathrm{h}$, and radioactivity was determined on 50- $\mu \mathrm{L}$ aliquots. Methyl $\alpha$-D-glucopyranoside was monitored by the phenol$\mathrm{H}_{2} \mathrm{SO}_{4}$ reaction ${ }^{32}$ carricd out on $2-\mu \mathrm{L}$ aliquots (absorbance at $490 \mathrm{~nm}$ ). The recovery of radioactivity was $94 \%$ (Fig. 5D).

The eluates from several Bio-Gel P-6DG columns (290 000 d.p.m.) were lyophilized, the residues were dissolved in solvent $A$, and the solution $(15 \mathrm{~mL})$ was loaded onto a DEAE-cellulose DE-52 column $\left(1 \times 13.5 \mathrm{~cm}\right.$; $\left.\mathrm{AcO}^{-}\right)$. This was washed successively with solvent $A(160 \mathrm{~mL})$, solvent $A-10 \mathrm{~mm}$ ammonium acetate $(190 \mathrm{~mL})$, and solvent $D-100 \mathrm{~mm}$ ammonium acetate $(220 \mathrm{~mL})$ at a maximum flow rate of $21 \mathrm{~mL} / \mathrm{h}$. Fractions $(5 \mathrm{~mL})$ were collected, and aliquots were examined for u.v. absorbance and for radioactivity $(0.5 \mathrm{~mL}$ except for the solvent $\mathrm{D}$ eluate, where $0.1 \mathrm{~mL}$ sufficed). The radioactively labeled fractions were pooled, concentrated, and lyophilized. Ammonium acetate was removed by repeated additions of water followed by lyophilization. The recovery of radioactivity was $60 \%$. 


\section{ACKNOWLEDGMENTS}

Financial support from I.N.S.E.R.M. to J. Badet is gratefully acknowledged. The authors thank Dr. C. D. Warren for oligosaccharide intermediates and Ms. B. Bugge for helpful suggestions.

\section{REFERENCES}

1 J. Badet and R. W. Jeanloz, Proc. Int. Symp. Glycoconjugates, VIIIth, (1985) 189.

2 M. D. SNider, in V. Ginsburg and P. W. Robilns (Eds.), Biology of Carbohydrates, Vol. 2, Wiley, New York, 1984, pp. 163-198.

3 R. Kornfeld and S. Kornfeld, Annu. Rev. Biochem., 54 (1985) 631-664.

4 A. Chapman, E. Li, and S. Kornfeld, J. Biol. Chem., 254 (1979) 10 243-10 249.

5 I. K. ViJay and G. H. Perdew, J. Biol. Chem., 255 (1980) 11 221-11 226.

6 I. K. Vijay and G. H. Perdew, Arch. Biochem. Biophys., 220 (1983) 605-614.

7 J. I. Rearick, A. Chapman. and S. Kornfeld, J. Biol. Chem.. 256 (1981) 6255-6261.

8 C. Prakasi, A. Katlal, M. S. Kang. and I. K. Vuay, Eur. J. Biochem., 139 (1984) 87-93.

9 R. G. Spiro, M. J. Spiro. And V. D. Bhoyroo, J. Biol. Chem., 251 (1976) 6409-6419.

10 J. W. Rip. N. Chaudhary. and K. K. Carroll. J. Biol. Chem., 258 (1983) $14926-14930$.

11 J. T. Mil.l. And A. M. Adamany, Int. Rev. Cytology, 73 (1981) 103-147.

12 E. Tabora and N. Behrens, Mol. Cell. Biochem., 16 (1977) 193-196.

13 J. S. Schutzbach, J. D. Springfifidd. and J. W. Jensen, J. Biol. Chem., 255 (1980) 4170-4175.

14 A. Herscovics, A. M. Golovtchenko, C. D. Warken, B. Bugge. and R. W. Jeanloz, J. Biol. Chem., 252 (1977) 22+234.

15 A. Herscovics, B. Bugge, and R. W. Jeanloz, J. Biol. Chem., 252 (1977) 2271-2277.

16 J. Chambers, W. T. Forsfe, And A. D. Elbein, J. Biol. Chem., 151 (1977) 2498-2506.

17 R. J. Staneloni, R. A. Ugalde, and L. F. Leloir, Eur. J. Biochem., 105 (1980) 275-278.

18 T. Liu. B. Stetson, S. J. Turco, S. C. Hubbard. and P. W. Robbins, J. Biol. Chem., 254 (1979) $4554-4559$.

19 S. C. Hubbard and P. W. Robbins. J. Biol. Chem., 254 (1979) 4568-4576.

20 M. D. Snider and O. C. Rogers, Cell, 36 (1984) 753-761.

21 E. C. Heath, J. W. Baynes, and A. F. Hsu, in Y. C. Lee and E. E. Smith (Eds.), Biology and Chemistry of Eucaryotic Cell Surfaces, Academic Press, New York, 1974, pp. 181-212.

22 S. Narasimhan, J. C. Freed. And H. SChachter, Carbohydr. Res., 149 (1986) 65-83: M. Biswas. Y. Sekharudu. and V. S. R. Rao, Carbohydr. Res., 160 (1987) 151-170.

23 A. Kobata, Anal. Biochem., 100 (1979) 1-14.

24 E. Li And S. Kornfei.d, J. Biol. Chem., 254 (1979) 2754-2758.

25 E. Li, I. Tabas, ANd S. Kornfeld, J. Biol. Chem., 253 (1978) 7762-7770.

26 L. S. Grinna and P. W. Robbins, J. Biol. Chem., 255 (1980) 2255-2258.

27 M. J. SPiro, R. G. Spiro. ANd V. D. Bhoyroo, J. Biol. Chem., 251 (1976) 6420-6425.

28 T. H. Plummer, J. Biol. Chem., 243 (1968) 5961-5966.

29 J. W. Baynes and F. Wol.d, J. Biol. Chem., 251 (1976) 6016-6024.

30 D. D. Carson. B. J. Earles. and W. J. Lennarz. J. Biol. Chem., 256 (1981) $11552-11557$.

31 O. H. Lowry, N. J. Rosebrough, A. L. Farr. and R. J. Randal., J. Biol. Chem., 193 (1951) 265-275.

32 M. Dubois, K. A. Gilles, J. K. Hamilton, P. A. Rebfrs, and F. Smith, Anal. Chem., 28 (1956) 350-356.

33 J. L. Reissig. J. L. Strominger, And L. F. Lel.oir, J. Biol. Chem., 217 (1955) 959-966.

34 C. G. Duck-Chong, Lipids, 14 (1979) 492-497.

35 P. F. Daniel, C. D. Warren, L. F. Jamfs, and R. D. Jolly, in A. A. Seawright, M. P. Hegarty, L. F. James, and R. F. Keeler (Eds.), The Queensland Poisonous Plants Committee, Queensland, Australia, 1985, pp. 290-300. 
36 R. J. Chalifour and R. G. Spiro, Arch. Biochem. Biophys., 229 (1984) 386-394.

37 G. Rouser, G. Kritchevsky, A. Yamamoto, G. Simon, C. Galli, and A. J. Baumann, Methods Enzymol., 14 (1969) 272-317.

38 S. I. Ogata, T. Muramatsu, and A. Kobata, J. Biochem. (Tokyo), 78 (1985) 687-696.

39 L. A. Quesada-Allue and A. J. Parodi, Biochem. J., 212 (1983) 123-128. 